\title{
Prevalence and Genetic Diversity of Avian Haemosporidian Parasites in Southern Iran
}

\author{
Vajiheh Ghaemitalab $^{1}\left(\mathbb{D}\right.$, Omid Mirshamsi $^{1,2}$, Gediminas Valkiūnas ${ }^{3}$ and Mansour Aliabadian ${ }^{1,2, *}$ \\ 1 Department of Biology, Faculty of Science, Ferdowsi University of Mashhad, Mashhad 9177948974, Iran; \\ ghaemitalab.vajihe@mail.um.ac.ir (V.G.); mirshams@um.ac.ir (O.M.) \\ 2 Research Department of Zoological Innovations (RDZI), Institute of Applied Zoology, Faculty of Science, \\ Ferdowsi University of Mashhad, Mashhad 9177948974, Iran \\ 3 Nature Research Centre, Akademijos 2, 08412 Vilnius, Lithuania; gediminas.valkiunas@gamtc.lt \\ * Correspondence: aliabadi@um.ac.ir; Tel.: +98-51-3880-5507
}

Citation: Ghaemitalab, V.;

Mirshamsi, O.; Valkiūnas, G.;

Aliabadian, M. Prevalence and Genetic Diversity of Avian Haemosporidian Parasites in Southern Iran. Pathogens 2021, 10, 645. https://doi.org/10.3390/ pathogens10060645

Academic Editor: Maria Grazia Pennisi

Received: 11 April 2021

Accepted: 20 May 2021

Published: 23 May 2021

Publisher's Note: MDPI stays neutral with regard to jurisdictional claims in published maps and institutional affiliations.

Copyright: (c) 2021 by the authors. Licensee MDPI, Basel, Switzerland. This article is an open access article distributed under the terms and conditions of the Creative Commons Attribution (CC BY) license (https:// creativecommons.org/licenses/by/ $4.0 /)$.

\begin{abstract}
Avian haemosporidians are widespread and diverse and are classified in the genera Plasmodium, Haemoproteus, Leucocytozoon, and Fallisia. These species are known to cause haemosporidiosis and decreased fitness of their hosts. Despite the high diversity of habitats and animal species in Iran, only few studies have addressed avian haemosporidians in this geographic area. This study was performed in the south and southeast of Iran during the bird breeding seasons in 2017 and 2018, with the aim to partly fill in this gap. Blood samples of 237 passerine birds belonging to 41 species and 20 families were collected. Parasite infections were identified using a nested PCR protocol targeting a 479-base-pair fragment of the mitochondrial cytochrome $b$ (cytb) gene of Haemoproteus, Plasmodium and Leucocytozoon species. The overall prevalence of haemosporidian parasites was $51.1 \%$, and 55 different lineages were identified, of which $15 c y t b$ lineages were new globally. The lineages of Haemoproteus predominated (63.6\% of all detected lineages), followed by Leucocytozoon and Plasmodium. Nineteen new host records of haemosporidian cytb lineages were identified, and the majority of them were found in resident bird species, indicating local transmission. Thirteen co-infections ( $9.8 \%$ of infected individuals) of Haemoproteus and Leucocytozoon parasites in seven host species were observed. This study shows the presence of active local transmission of parasites to resident bird species in the southeast of Iran and contributes to the knowledge on haemosporidian parasite biodiversity in this poorly studied region of the world.
\end{abstract}

Keywords: birds; haemosporidian parasites; Plasmodium; Haemoproteus; Leucocytozoon; Iran

\section{Introduction}

Haemosporidian parasites (Haemosporida) are widespread intracellular pathogens that infect many species of terrestrial vertebrates including birds, mammals and reptiles [1-4]. Avian haemosporidians is the largest group of haemosporidians in terms of number of described species and an excellent model for the study of host-parasite interactions [1,5]. The knowledge on prevalence, diversity and patterns of distribution of avian haemosporidians can be useful for better understanding various ecological, evolutionary, and behavioural questions [4], as well as important in conservation biology and disease risk assessment in veterinary medicine and wildlife populations $[2,6,7]$. This is particularly true for coinfections with two or more different haemosporidian parasites, which could lead to disease, accompanied by anaemia, loss of body mass and reduced survival in hosts $[8,9]$.

The haemosporidian parasites of birds belong to the genera Plasmodium Marchiafava and Celli 1885, Haemoproteus Kruse 1890, Leucocytozoon Berestneff 1904 and Fallisia Lainson, Landau and Shaw 1974, which have been detected all around the world except in Antarctica [1,10]. Fallisia parasites were found in birds only in South America. Since the development of molecular identification of avian haemosporidians using fragments of 
the mitochondrial cytochrome $b$ gene [11,12], the number of scientific publications, parasite lineages and bird taxa studied has remarkably increased $[13,14]$. These findings have revealed much higher than expected levels of parasites diversity [7]. Based on the MalAvi database (a Public Database of Malaria Parasites and Related Haemosporidians in Avian Hosts, www.mbio-serv2.mbioekol.lu.se, accessed on 1 May 2021), over 3600 unique haemosporidian lineages have been reported in about $20 \%$ of bird species worldwide. Furthermore, co-infection with two or more different haemosporidian parasites was shown to be common in wild birds [6,15-17].

Iran is an important area of bird biodiversity [18]. Its territory was classified in four eco-zones, located in the north (eastern and western Palearctic), south (Afrotropical) and southeast (Oriental) of the country [19]. These geographical areas are characterized not only by markedly different habitats but also by bird species diversity [20]. However, information about malaria and related haemosporidian parasite diversity remains insufficiently studied in Iran, and this is an obstacle for better understanding these parasite biodiversity patterns in southern Asia. In recent years, several studies have addressed avian haemosporidians, mainly in domestic and aquatic birds in Iran [21-29]. Nevertheless, a few studies have been conducted on haemosporidians of songbirds [30,31].

The order Passeriformes (passerines) includes more than $60 \%$ of described bird species and is the largest and most species-diverse avian order [32]. It includes 230 species belonging to 32 families inhabiting diverse habitats in Iran. About 110 passerine species are residents or summer breeding in southern parts of the country [33]. However, few studies examined their blood parasites in this region. Resident non-migrating bird species are of particular interest for parasitology research, because their parasite fauna develops locally and is an indication of local parasite transmission. This study aimed to identify the $c y t b$ lineages of Plasmodium, Haemoproteus and Leucocytozoon in passerines over the southwest to the southeast of Iran in six provinces and to determine the prevalence and genetic diversity of these pathogens. This knowledge is important for a better understanding of the epidemiological situation regarding haemosporidiosis in Iran and will also contribute with valuable data to the description of the biogeography and biodiversity of avian haemosporidians.

\section{Results}

\subsection{Parasite Prevalence}

According to PCR-based testing, 121 of 237 songbird individuals (overall prevalence $51.1 \%$ ), belonging to 14 families, 20 genera and 30 species were positive for Plasmodium, Haemoproteus and Leucocytozoon species (Table 1). Species of the Passeridae and Sylviidae were the most prevalently infected $(44.6 \%$ and $19.0 \%$, respectively). Prevalence of haemosporidian infections in the sampled localities varied from 32.2\% (Khuzestan) to $2.5 \%$ (Hormozgan) (Figure 1).

Table 1. Avian haemosporidian parasite diversity and prevalence in birds sampled in southern Iran. Parasite species, cytochrome $b$ lineage GenBank accessions and migration status of bird species are shown. Newly detected lineages are given in bold.

\begin{tabular}{|c|c|c|c|c|c|c|}
\hline Host Family and Species & Study Site & Migration Status & $\mathbf{N}^{\mathrm{a}}$ & Parasite Species & $\begin{array}{l}\text { Lineage (GenBank } \\
\text { Accession) }\end{array}$ & $\begin{array}{c}\text { Molecular Prevalence of } \\
\text { Lineage }(\%)^{b}\end{array}$ \\
\hline \multicolumn{7}{|l|}{ Acrocephalidae } \\
\hline \multirow{4}{*}{ Acrocephalus arundinaceus ${ }^{\mathrm{c}}$} & \multirow{4}{*}{ A, B } & \multirow{4}{*}{$\mathrm{P}$} & \multirow{4}{*}{6} & Leucocytozoon sp. & AFR214 (MT925903) & $1(16.7)$ \\
\hline & & & & \multirow{2}{*}{$\begin{array}{c}\text { Haemoproteus sp. } \\
\text { Haemoproteus } \\
\text { nucleocondensus }\end{array}$} & SW4 (MT925861) & $1(16.7)$ \\
\hline & & & & & GRW01 (MT925867) & $1(16.7)$ \\
\hline & & & & Plasmodium sp. & SYBOR10 (MT925889) & $1(16.7)$ \\
\hline Acrocephalus dumetorum & G & B P & 1 & 0 & 0 & 0 \\
\hline \multirow{2}{*}{ Acrocephalus palustris } & \multirow{2}{*}{ B } & \multirow{2}{*}{ B P } & \multirow{2}{*}{4} & Haemoproteus belopolskyi & ARW1 (MT925863) & $1(25.0)$ \\
\hline & & & & Haemoproteus sp. & MW3 (MT925871) & $1(25.0)$ \\
\hline \multirow{2}{*}{ Acrocephalus scirpaceus } & \multirow{2}{*}{ B } & \multirow{2}{*}{ B } & \multirow{2}{*}{7} & Haemoproteus belopolskyi. & ARW1 (MT925863) & $1(14.3)$ \\
\hline & & & & Haemoproteus belopolskyi & MW1 (MT925870) & $1(14.3)$ \\
\hline $\begin{array}{l}\text { Iduna pallida } \\
\text { Alaudidae }\end{array}$ & A, B & B & 4 & Haemoproteus sp. & HIP2 (MT925849) & $2(50.0)$ \\
\hline Calandrellabrachydactyla & G & B & 2 & Leucocytozoon sp. & WW6 (MT925894) & $1(50.0)$ \\
\hline Galerida cristata & $\mathrm{H}$ & $\mathrm{R}$ & 1 & 0 & 0 & 0 \\
\hline
\end{tabular}


Table 1. Cont.

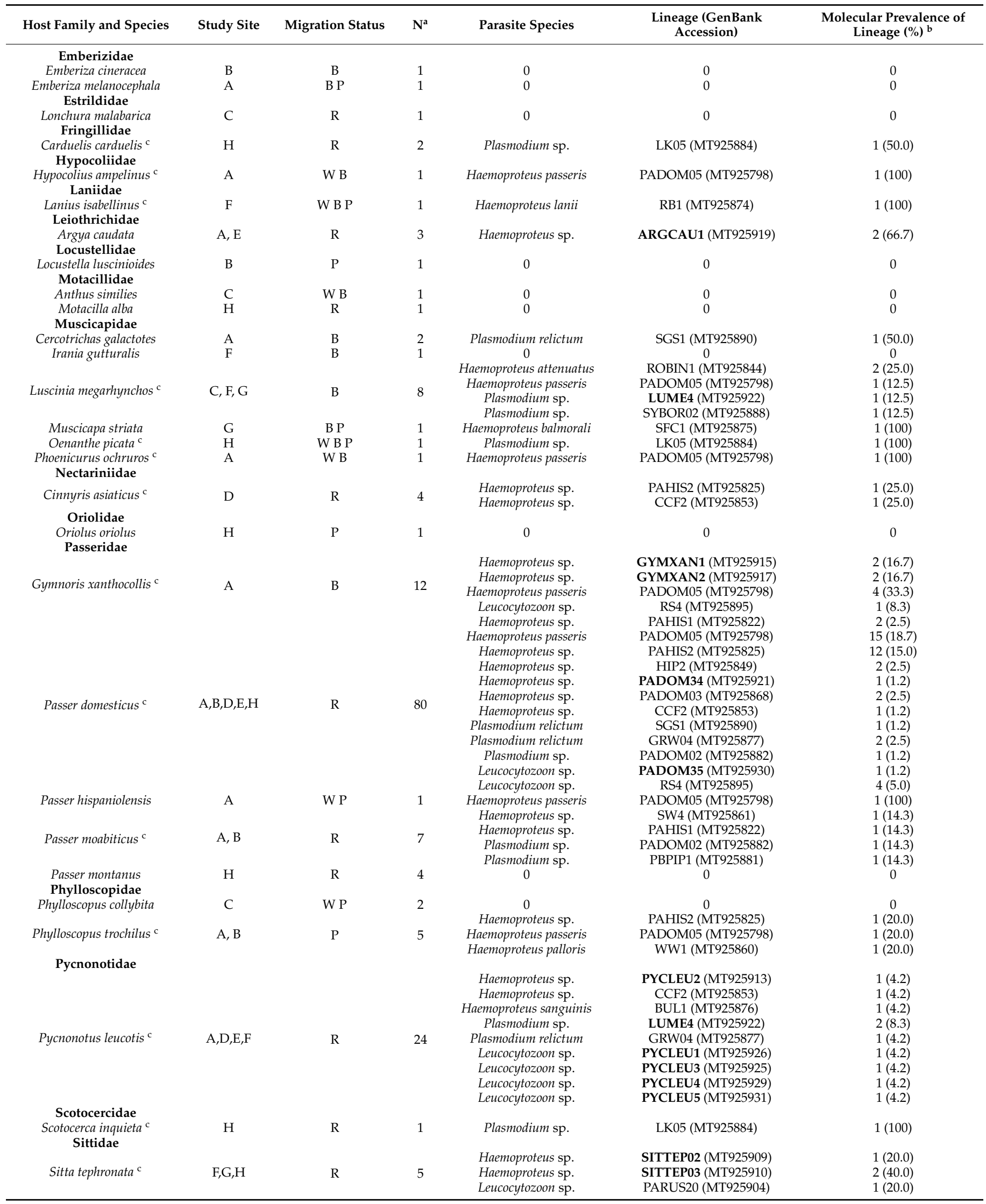


Table 1. Cont.

\begin{tabular}{|c|c|c|c|c|c|c|}
\hline Host Family and Species & Study Site & Migration Status & $\mathbf{N}^{\mathrm{a}}$ & Parasite Species & $\begin{array}{l}\text { Lineage (GenBank } \\
\text { Accession) }\end{array}$ & $\begin{array}{c}\text { Molecular Prevalence of } \\
\text { Lineage (\%) }\end{array}$ \\
\hline Sturnidae & & & & & & \\
\hline \multirow{4}{*}{$\begin{array}{l}\text { Sturnus roseus } \\
\text { Sylviidae }\end{array}$} & $\mathrm{H}$ & B & 1 & 0 & 0 & 0 \\
\hline & & & & Haemoproteus sp. & SYHOR01 (MT925840) & $4(44.4)$ \\
\hline & & & & Haemoproteus sp. & SYLALT01 (MT925912) & $1(11.1)$ \\
\hline & & & & Haemoproteus sp. & CURCUR01 (MT925872) & $1(11.1)$ \\
\hline \multirow{5}{*}{ Sylvia althaea ${ }^{\mathrm{c}}$} & $\mathrm{F}, \mathrm{G}, \mathrm{H}$ & $\mathrm{B}$ & 9 & Haemoproteus sp. & LWT1 (MT925873) & $1(11.1)$ \\
\hline & & & & Leucocytozoon sp. & SYBOR07 (MT925892) & $1(11.1)$ \\
\hline & & & & Leucocytozoon sp. & SFC8 (MT925893) & $1(11.1)$ \\
\hline & & & & Leucocytozoon sp. & SYNIS4 (MT925927) & $1(11.1)$ \\
\hline & & & & Haemoproteus sp. & PAHIS2 (MT925825) & $1(14.3)$ \\
\hline \multirow[t]{6}{*}{ Sylvia atricapilla ${ }^{\mathrm{c}}$} & A & $\mathrm{P}$ & 7 & $\begin{array}{l}\text { Haemoproteus } \\
\text { parabelopolskyi }\end{array}$ & SYAT01 (MT925846) & $1(14.3)$ \\
\hline & & & & $\begin{array}{l}\text { Haemoproteus } \\
\text { parabelopolskyi }\end{array}$ & SYAT07 (MT925847) & $2(28.6)$ \\
\hline & & & & Leucocytozoon sp. & SYAT22 (MT925906) & $3(42.8)$ \\
\hline & & & & Haemoproteus sp. & SYNIS2 (MT925859) & $1(8.3)$ \\
\hline & & & & Haemoproteus sp. & CWT2 (MT925856) & $2(16.7)$ \\
\hline & & & & Haemoproteus sp. & CWT3 (MT925865) & $2(16.7)$ \\
\hline \multirow{3}{*}{ Sylvia communis ${ }^{c}$} & A & $\mathrm{P}$ & 12 & Haemoproteus sp. & CWT7 (MT925858) & $1(8.3)$ \\
\hline & & & & Leucocytozoon $\mathrm{sp}$. & RS4 (MT925895) & $3(25.0)$ \\
\hline & & & & Leucocytozoon $\mathrm{sp}$. & SYCON05 (MT925905) & $1(8.3)$ \\
\hline Sylvia curruca $^{\mathrm{c}}$ & $\mathrm{A}, \mathrm{B}, \mathrm{C}$ & $\mathrm{P}$ & 4 & Plasmodium sp. & LK05 (MT925884) & $1(25.0)$ \\
\hline Sylvia mystacea & A & $\mathrm{P}$ & 1 & Plasmodium relictum & GRW04 (MT925877) & $1(100)$ \\
\hline Sylvia nisoria & A,B & $\mathrm{P}$ & 4 & Haemoproteus sp. & PYCLEU2 (MT925913) & $1(25.0)$ \\
\hline & & & & Leucocytozoon sp. & SYNIS4 (MT925927) & $1(25.0)$ \\
\hline $\begin{array}{c}20 \text { familles, } 29 \text { genera, } 41 \\
\text { species }\end{array}$ & 8 sites & $\begin{array}{l}4 \text { migration status } \\
\text { birds }\end{array}$ & 237 & 13 parasite species & 55 lineages & $\begin{array}{l}\text { Overall prevalence } 121 \\
(51.1)\end{array}$ \\
\hline
\end{tabular}

Study sites: A, Khuzestan province; B, Bushehr province; C, Hormozgan province; D, Rask (Sistan and Baluchistan province); E, Saravan (Sistan and Baluchistan province); F, Bam (Kerman province); G, Baft (Kerman province); H, South Khorasan province. Migration status: W $=$ Wintering, $\mathrm{B}=$ Breeding, $\mathrm{R}=$ Resident, $\mathrm{P}=$ Passengers. $\mathrm{N}^{\mathrm{a}}$ : Number of sampled individuals. Superscript $\mathrm{b}\left({ }^{\mathrm{b}}\right)$ : Number of detected

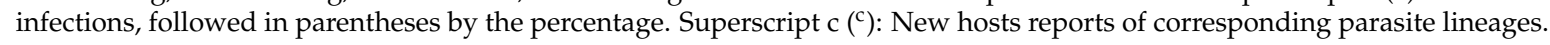

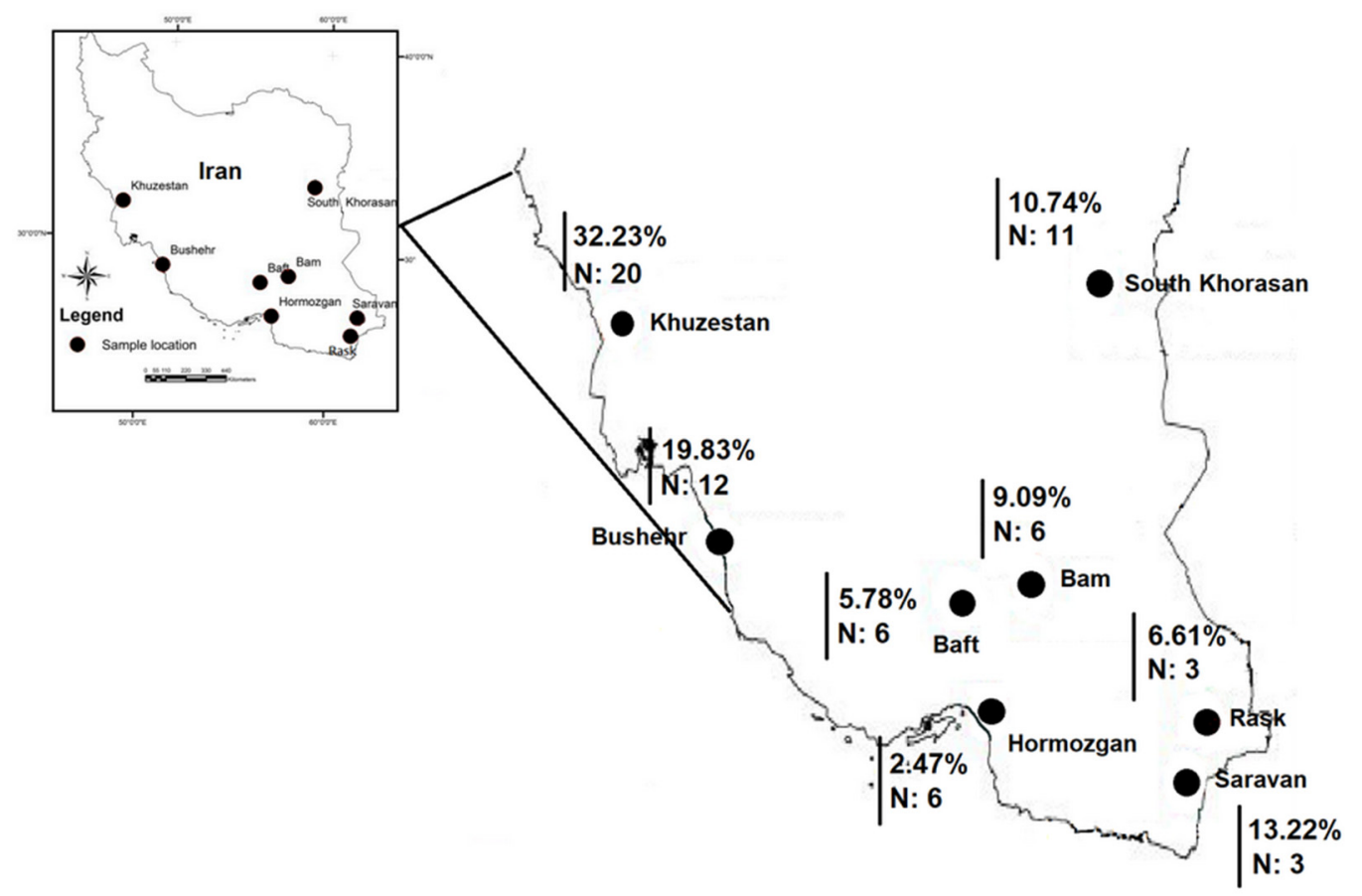

Figure 1. The localities in southern Iran where birds were examined. Sampling localities (black dots) are Khuzestan, Bushehr, Hormozgan, South Khorasan provinces, Rask (Sistan and Baluchistan province), Saravan (Sistan and Baluchistan province), Bam (Kerman province), Baft (Kerman province). Prevalence of infection (in percentage) is shown in each locality. N: number of sampled host species in each locality. The map was prepared using ArcGIS 10 (Arc Geographic Information System). 


\subsection{Lineage Diversity}

In total, 55 different haemosporidian parasite lineages were detected, of which 8 Plasmodium lineages (14.5\% of all reported lineages), 35 Haemoproteus $(63.6 \%)$ and 12 Leucocytozoon (21.8\%). The highest lineage diversity was observed in birds of the Sylviidae and Passeridae families, with 21 and 16 different lineages found, respectively. Information about 15 novel lineages and the other identified lineages is given in Table 1.

According to the MalAvi database, 13 lineages completely matched up with the lineages of previously described morphospecies: Haemoproteus lanii (RB1), Haemoproteus attenuatus (ROBIN1), Haemoproteus passeris (PADOM05), Haemoproteus balmorali (SFC1), Haemoproteus parabelopolskyi (SYAT01 and SYAT07), Haemoproteus palloris (WW1), Haemoproteus belopolskyi (ARW1 and MW1), Haemoproteus nucleocondensus (GRW01), Haemoproteus sanguinis (BUL1), Plasmodium relictum (GRW04 and SGS1) (Table 1). We identified 19 new host records for 21 previously known lineages; these records are shown in Table 1.

\subsection{Co-Infection}

We detected 13 co-infections of Haemoproteus spp. and Leucocytozoon spp. (Table 2). Coinfection of Haemoproteus spp. and Plasmodium spp. or Plasmodium spp. and Leucocytozoon spp. was not observed. Based on Pearson correlation, the probabilities of co-infection by Haemoproteus and Leucocytozoon parasites were not correlated (sig $=0.10$, correlation was considered significant at the $<0.01$ level), but were negatively correlated with the occurrence of Plasmodium infection (sig $=0.00)$. We also identified 16 unresolved coinfections (unresolved double peaks) of parasites belonging to three haemosporidian genera, of which 7 belonged to Haemoproteus spp. lineages, 8 to Leucocytozoon spp. lineages and 1 to Plasmodium spp. lineages; these infections were excluded from further analysis and discussion.

Table 2. Co-infection of Haemoproteus spp. and Leucocytozoon spp. lineages in birds sampled in southern Iran. Cytochrome $b$ lineage GenBank accession numbers are given in parentheses.

\begin{tabular}{|c|c|c|c|c|}
\hline Host Species & $\begin{array}{l}\text { Haemoproteus Lineage } \\
\text { (GenBank Accession) }\end{array}$ & $\begin{array}{l}\text { Leucocytozoon Lineage } \\
\text { (GenBank Accession) }\end{array}$ & $\mathbf{N}^{\mathbf{a}}$ & Study Site ${ }^{b}$ \\
\hline Sylvia althaea & SYHOR01 (MT925840) & SYBOR07 (MT925892) & 1 & $\mathrm{~F}$ \\
\hline S. althaea & LWT1 (MT925873) & SFC8 (MT925893) & 1 & $\mathrm{~F}$ \\
\hline S. althaea & CURCUR01 (MT925872) & SYNIS4 (MT925927) & 1 & $\mathrm{H}$ \\
\hline S. atricapilla & SYAT07 (MT925847) & SYAT22 (MT925906) & 2 & A \\
\hline S. atricapilla & PAHIS2 (MT925825) & SYAT22 (MT925906) & 1 & A \\
\hline S. communis & SYNIS2 (MT925859) & RS4 (MT925895) & 1 & A \\
\hline S. communis & CWT2 (MT925856) & RS4 (MT925895) & 1 & A \\
\hline Passer domesticus & PAHIS2 (MT925825) & RS4 (MT925895) & 1 & A \\
\hline P. domesticus & PADOM05 (MT925798) & RS4 (MT925895) & 2 & $\mathrm{E}$ \\
\hline P. domesticus & HIP2 (MT925849) & RS4 (MT925895) & 1 & $\mathrm{E}$ \\
\hline Pycnonotus leucotis & BUL1 (MT925876) & PYCLEU5 (MT925931) & 1 & $\mathrm{C}$ \\
\hline Total & 10 lineages & 6 lineages & 13 & 5 sites \\
\hline
\end{tabular}

$\mathrm{N}^{\mathrm{a}}$ : Number of co-infections identified. Superscript $\mathrm{b}\left({ }^{\mathrm{b}}\right)$ : Study site abbreviations are as in Table 1.

\section{Discussion}

The key result of this study is the determination of the high prevalence and genetic diversity of avian haemosporidian parasite lineages in southern Iran, a formerly nonstudied area in this regard. The studied localities cover a wide geographical area, including six provinces located in the Khuzestan province in the southwest, to Sistan and Baluchistan and South Khorasan provinces in the southeast and east of Iran (Figure 1). This study shows a high prevalence of haemosporidian parasites infecting wild Passeriformes birds, detected in over half of the examined bird species (Table 1). Briefly, these pathogens were detected in $73.3 \%$ of the examined bird species ( $\mathrm{N}=30 / 41$ ), which belonged to $69 \%$ of the examined genera $(N=20 / 29)$ and $68.4 \%$ of the examined families $(N=14 / 20)$. Among all examined birds, the species of Passeridae (44.6\% prevalence) and Sylviidae $(19.0 \%)$ were the most prevalently infected. One-way ANOVA with post-hoc tests showed that infection 
prevalence in birds of the examined families was significantly different for parasites of the Haemoproteus and Leucocytozoon genera (sig $=0.01$ and sig $=0.00$, respectively, $p<0.05$ ), but was not significantly different for the parasites of the Plasmodium genus.

The highest haemosporidian parasite infection prevalence was observed in Khuzestan $(32.2 \%)$ and Bushehr $(19.8 \%)$ provinces (Figure 1). The studied sites in these provinces were near rivers or marshes. According to previous studies [34,35], the availability of water bodies and a high humidity can increase the prevalence of haemosporidians due to a greater abundance of blood-sucking dipteran vectors. It is thus suggested to investigate the correlation between these environmental factors and the prevalence of haemosporidians in these regions in future studies.

Fifty-five haemosporidian parasite lineages were detected. Fifteen lineages were new, being previously unknown parasite lineages worldwide (Table 1); among them, the lineages of Haemoproteus spp. (53.3\% of all new lineages) and Leucocytozoon spp. $(40 \%)$ predominated. New Plasmodium spp. lineages were rare $(6.6 \%$ of new lineages). Interestingly, about $40 \%$ of the new lineages were found in White-eared Bulbul (Pycnonotus leucotis). This bird species is resident in southern parts of Iran [33], indicating that local transmission of the reported parasites occurs in Iran. This bird species deserves attention as a convenient model organism for research aiming to a better understanding of the local epidemiology of avian haemosporidiosis.

Thirty-five lineages were identified as belonging to Haemoproteus (63.6\% of all reported lineages). The most prevalent were the lineages PADOM05, PAHIS2, CCF2, hHIP2 and SW4. The PADOM05 lineage belongs to Haemoproteus passeris [36], and its presence and high prevalence in Iran is congruent with a previous study [31]. This parasite has been reported in all zoogeographical regions except for the Antarctic [1] and is common around the Mediterranean Sea and in Central Europe [37]. The lineage PADOM05 was reported in Dead Sea sparrow (Passer moabiticus) and house sparrow (Passer domesticus) from the Eastern Mediterranean for the first time by Martinsen et al. [36,38]. The PADOM05 lineage was also reported in previous studies on birds of the Acrocephalidae, Sylviidae, Passeridae and Motacillidae families [31,36,38-46]. However, it remains unclear if birds other than species of the Passeridae are competent hosts for this parasite, because the PCR-based reports were not document by the presence of $H$. passeris gametocytes in the circulation. No study has reported this parasite species in non-passerine hosts according to the MalAvi database. Common nightingale (Luscinia megarhynchos), Black redstart (Phoenicurus ochruros), Yellowthroated sparrow (Gymnoris xanthocollis), Grey hypocolius (Hypocolius ampelinus) and Willow warbler (Phylloscopus trochilus), were recorded as new host species of the PADOM05 lineage in this study (Table 1). However, we also did not report gametocytes of H. passeris in these birds, and these hosts might be non-competent hosts for this parasite as well. Additional microscopic studies are needed to answer this question.

To date, the species identity of the lineages PAHIS2, CCF2, HIP2 and SW4 remains unclear. Some of them might belong to new parasite species, and further microscopic examinations are needed to answer this question. The lineage PAHIS2 was reported in previous studies in house sparrow and Spanish sparrow (Passer hispaniolensis) [31,41,44]. The Eurasian blackcap (Sylvia atricapilla), the willow warbler and the purple sunbird (Cinnyris asiaticus) were recorded as new host species for this lineage in this study. In previous studies, the CCF2 lineage was reported in birds of the Fringillidae, Paridae, Turdidae, Muscicapidae, Emberizidae and Hirundinidae families [41,46-51]. In this study, the lineage CCF2 was detected in white-eared bulbul, house sparrow and purple sunbird for the first time. The HIP2 lineage was reported only in the Eastern olivaceous warbler (Iduna pallida) and Booted warbler (Iduna caligata) of the Acrocephalidae family in previous studies $[31,47,51]$. The house sparrow was recorded as new host species for the HIP2 lineage in this study. Previously, the SW4 lineage was reported in the paddyfield warbler (Acrocephalus agricola) and Sedge warbler (Acrocephalus schoenobaenus) [52,53]. The great reed warbler (Acrocephalus arundinaceus) and house sparrow were recorded as new host species for this lineage in the current study. The other lineages of Haemoproteus spp. that 
were detected only in one host species were: PAHIS1, GRW01, ROBIN1, SFC1, SYHOR01, LWT1, SYAT01, SYAT07, RB1, BUL1, ARW1, MW1, MW3, PADOM03 and WW1 (Table 1).

The second most prevalent haemosporidian parasites were species of Leucocytozoon, with 12 identified lineages, and 5 of them were new lineages (21.8\% of all reported lineages). The lineage RS4 was the most prevalent lineage of Leucocytozoon spp., detected in different host species of different families. The species identity of this parasite remains unclear. The lineage RS4 was recorded in the common redstart (Phoenicurus phoenicurus), Eurasian blackcap, common whitethroat (Sylvia communis), berthelot's pipit (Anthus berthelotii), bluethroat (Luscinia svecica), forest fody (Foudia omissa), African stonechat (Saxicola torquata) in previous studies [51,52,54-56]. The house sparrow (Passer domesticus) and the yellowthroated sparrow were recorded as new host species for this lineage in this study. The other detected this genus lineages, which have been found in only one host species, were SYBOR07, SFC8, SYAT22, SYCON05, PARUS20 and AFR214 (Table 1).

Eight lineages of Plasmodium sp. were detected, and one lineage (LUME4, GenBank accession number MT925922) was new. The lineages LK05 and GRW04 were detected in different host species of different families. The LK05 lineage was detected in birds of four different families (Muscicapidae, Scotocercidae, Fringillidae and Sylviidae), while it was reported in species of the Falconidae, Motacillidae and Fringillidae previously [54,57-59]. Variable wheatear (Oenanthe picata), lesser whitethroat (Sylvia curruca), streaked scrub warbler (Scotocerca inquieta), European golden finch (Carduelis carduelis) are new host species for this malaria parasite lineage. The report of the same Plasmodium lineages in birds of different families was expected because avian malaria parasites often present broad vertebrate-host specificity and can complete their life cycle in birds belonging to different families and even orders $[1,2,4]$.

The lineages GRW04, GRW11, LZFUS01 and SGS1 belong to the cosmopolitan malaria parasite, Plasmodium relictum; this parasite species is of global distribution and parasitizes many bird species [1]. The GRW04 and SGS1 lineages of P. relictum, which were detected in this study, have a widespread distribution and are virulent in many bird species $[60,61]$. According to the MalAvi database, the GRW04 and SGS1 lineages have been found in birds of 11 orders and in 21 families of Passeriformes. These two parasites are often virulent in various species of avian hosts [61]. In this study, the GRW04 lineage was detected in birds of three different families: Sylviidae (menetries's warbler Sylvia mystacea), Passeridae (house sparrow) and Pycnonotidae (white-eared bulbul), and the SGS1 was detected in Muscicapidae (rufous-tailed scrub robin Cercotrichas galactotes) and Passeridae (house sparrow). It is interesting to note that the report of both these malaria lineages in nonmigrating house sparrow at same study sites indicate the local transmission in sympatry, providing opportunities to study the influence of this co-infection in birds during natural infection in the future. The lineages SYBOR02, SYBOR10, PADOM02 and PBPIP1 were found in only one host species (Table 1 ).

We detected 13 co-infections (9.8\% of all infected individuals) of Haemoproteus spp. and Leucocytozoon spp. lineages (Table 2). These co-infections were detected in five different host species. The lineages RS4 and SYAT22 of Leucocytozoon spp. were present most often in co-infections. The lineage RS4 was detected in five co-infections in two different host species (common whitethroat and house sparrow); it was present together with the lineages SYNIS2, CWT2, PAHIS2, PADOM05 and HIP2 (Haemoproteus spp.). The lineage SYAT22 (Leucocytozoon spp.) was detected in two co-infections in the Eurasian blackcap; it was present together with the PAHIS2 and SYAT07 (Haemoproteus spp.) lineages.

In this study, a Pearson correlation test of co-infection by Haemoproteus and Leucocytozoon parasites was not significant. Van Rooyen et al. [61] reported the presence of $82 \%$ co-infection by parasites belonging to different genera in great tits. They found more lineage diversity of Haemoproteus during co-infections with Leucocytozoon parasites and speculated that the parasites can more easily become established in hosts whose immune system is weakened by prior infections. However, this hypothesises cannot be supported by the data collected in this study, and further studies are needed to clarify this issue. 
For unclear reasons, we did not find any co-infection of Plasmodium and Leucocytozoon or Haemoproteus and Plasmodium parasites, while co-infections of these parasites are common in wildlife [5,16,62-65]. This might be due to preferable amplification of the DNA of Haemoproteus or Plasmodium parasite lineages in our samples during co-infections [66]. This study shows that the application of more sensitive diagnostic methods (parasite genus-specific primers or/and multiplex PCR essays) is essential to clarify this issue in the future $[67,68]$.

PCR-based methods often underestimate the diversity of haemosporidians during co-existence of genetically similar parasite lineages in co-infections $[66,69,70]$. Available PCR assays often preferentially amplify the DNA of one species in the same individual bird co-infected with two different parasites of the Plasmodium and Haemoproteus genera [66,71]. On the other hand, the parasite lineages presented in a sample and the DNA quantity and quality may affect a study results $[69,72,73]$. Using both PCR-based and microscopic methods in parallel can increase the detectability of haemosporidian infections, especially co-infections of different parasites in wild bird populations [74,75] and is worth application in wildlife haemosporidian research. We excluded 16 parasite DNA sequences, which were identified as unresolved co-infections from our analysis because their identification was impossible through the PCR-based method.

One-way ANOVA test results showed that the most prevalently infected birds were species of the Passeridae, and the biggest lineage diversity was seen in species of the Sylviidae. Valkiūnas [1] reported a high prevalence of haemosporidian parasites in birds of the Sylviidae family in Europe. In our study, four species of Sylvia were most prevalently infected with haemosporidian parasites. These are Hume's whitethroat (Sylvia althaea) $(5.8 \%$ prevalence), barred warbler (Sylvia nisoria) 1.6\%, Eurasian blackcap 3.3\% and common whitethroat $6.6 \%$. More than half of individuals of these four species showed double infection with Haemoproteus and Leucocytozoon parasites, and some of them were unresolved co-infections and were removed from analysis. On the other hand, the co-infection rate in the house sparrow was only $9.5 \%$, despite the big sample size (80 specimens). The prevalence of Haemoproteus infection in the house sparrow was $15.2 \%$, but only $5 \%$ of house sparrows were infected with both Haemoproteus and Leucocytozoon parasites. It seems that the house sparrow can be partially resistant to the haemoproteids normally developing in other songbirds [37]. According to Loiseau et al. [76], specific MHC (major histocompatibility complex) alleles, which are associated with susceptibility to Plasmodium spp. in a population of house sparrows, can confer resistance to a co-infection with Haemoproteus spp. Based on the MalAvi database, 46 lineages of Plasmodium spp., 28 lineages of Haemoproteus spp. and only 6 lineages of Leucocytozoon spp. were reported in house sparrows. Many more lineages (47 lineages of Haemoproteus spp., 14 of Leucocytozoon spp. and 9 of Plasmodium spp.) were reported in the above-mentioned species of Sylvia around the world. The available data might indicate a relatively higher natural resistance in house sparrows to these infections in comparison to species of the genus Sylvia, which probably are more susceptible to Haemoproteus and Leucocytozoon infections. These results might also indicate that house sparrows have higher resistance to Leucocytozoon parasites. However, this issue still needs to be studied more extensively. Defence strategies during infection vary among different host species; therefore, some bird species are more resistant to same parasites than others [77]. Palinauskas et al. [78] showed that starlings were resistant to single and double experimental malaria infections, but many other passeriform bird species were susceptible. Van Rooyen et al. [62] showed that great tits (Parus major) were more resistant to Leucocytozoon parasites than to Haemoproteus and Plasmodium parasites. In addition to host immune defence, within-host competition between parasites, patterns of local transmission and availability of vectors can affect the occurrence of co-infection in certain avian hosts $[62,77,79]$.

About half of the co-infections were observed in Khuzestan (Karkheh protected area) (Table 2), indicating the high rate of transmission at this study site, probably due to a high abundance of vectors [1]. Climatic and habitat conditions are important factors affecting the activity and abundance of vectors [80,81]; this needs further investigation in this area. 
Many studies reported co-infections with haemosporidian parasites belonging to different genera. Valkiūnas et al. [63] found that $86.0 \%$ of the examined hawfinches Coccothraustes coccothraustes were co-infected with haemosporidian parasites belonging to different genera. Marzal et al. [5] detected $16 \%$ of double infections with Haemoproteus spp. and Plasmodium spp. lineages in house martins. Zehtindjiev et al. [82] reported the death of great reed warblers after co-infection with two Plasmodium species. Van Rooyen et al. [62] reported co-infection in $81.5 \%$ of infected great tits, including various combinations of Plasmodium or Haemoproteus and Leucocytozoon. Schoener et al. [83] found co-infection of Plasmodium lineages in blackbirds (Turdus merula) and song thrushes (Turdus philomelos) in New Zealand. Some studies have shown that co-infection with parasites of different haemosporidian genera can increase pathogen virulence and mortality in the host populations $[5,84,85]$. Due to short-term field study, we likely missed the acute primary infection stage during haemosporidian parasite co-infections, and further studies are needed for a better understanding of the mortality and epidemiology of such infections.

We detected $116(48.9 \%)$ haemosporidian-free individuals in 237 sampled passerines. These uninfected individuals were mostly from bird groups with less than five sampled individuals that belonged to 11 families, 12 genera and 13 species (Table 1).

Along with the results of this study (Table 1), 33 formerly known lineages were reported in resident bird species in Iran (based on the MalAvi database). We reported for the first time haemosporidian infections in a non-migrating passerine species in the southern parts of Iran, the white-eared bulbul. This bird is the resident species, which is common in palm trees and gardens in regions in southern parts of Iran as well as in Iraq and Syria [86]. Half of the examined individuals of white-eared bulbul were infected by haemosporidian parasites, and $7.8 \%$ of the co-infections were also detected in this species (Table 2). In all, nine lineages were found in this species, of which six were new. The lineages CCF2, BUL1 and GRW04 were detected in this species, indicating the local transmission of these parasites. These data are in accordance with a report of the GRW04 and pSGS1 lineages in the non-migratory house sparrow in Iran (Table 1). Both these bird species can be recommended as a good model of avian hosts for the investigation of locally transmitted haemosporidian infections and of haemosporidiosis epidemiology in Iran.

\section{Materials and Methods}

\subsection{Collection of the Samples}

Collection of the samples was performed in south and southeast of Iran from 2017 (February to July) to 2018 (April to July). Birds were sampled at eight different sites in six provinces using mist nets, as shown in Figure 1. Data about the sampled birds belonging to different families, genera and species at each site are shown in Table 1.

In total, blood samples from 237 songbirds belonging to 29 genera, 41 species and 20 families were collected. Bird species were identified according to Svensson [86]. A drop of blood was taken from each bird by puncturing the brachial vein with sterile insulin needles. About $30 \mu \mathrm{L}$ of blood was collected in heparinized microcapillaries and stored in $1.5 \mathrm{~mL}$ microcentrifuge tubes containing about $700 \mu \mathrm{L}$ of Queens's buffer at ambient temperature while in the field, and then preserved at $-20^{\circ} \mathrm{C}$ in the laboratory. All birds were released after sampling, and all efforts were made to minimize their suffering.

\subsection{DNA Extraction, PCR and Sequencing}

Total genomic DNA extraction was conducted using the standard salt extraction method described by Bruford et al. [87]. All collected samples were processed using a nested PCR protocol [88] targeting a 479-base-pair fragment of the cytb gene of Haemoproteus, Plasmodium and Leucocytozoon species. Initial PCR was performed with the primers HaemFN1/HaemR3N which amplified the DNA of parasites belonging to all three genera, i.e., Plasmodium, Haemoproteus and Leucocytozoon. The PCR reaction was performed in $25 \mu \mathrm{L}$ total volume containing $1.5 \mu \mathrm{L} \mathrm{MgCl} 2(25 \mathrm{mM}), 2.5 \mu \mathrm{L}$ GeneAmp $10 \times$ PCR Buffer, $2.5 \mu \mathrm{L}$ $\mathrm{dNTP}(1.25 \mathrm{mM}), 0.1 \mu \mathrm{L}$ AmpliTaq DNA polymerase $(5 \mathrm{U} / \mu \mathrm{L}), 0.6 \mathrm{mM}$ of each primer, 
$15.4 \mu \mathrm{L}$ of double distilled $\mathrm{H} 2 \mathrm{O}$ and $1 \mu \mathrm{L}$ of diluted total genomic DNA template $(25 \mathrm{ng} / \mu \mathrm{L})$, per reaction; subsequent PCR was performed with the primers HaemF/HaemR2 for Plasmodium and Haemoproteus and HaemFL/HaemR2L for Leucocytozoon parasites. The nested PCR reaction was also performed in $25 \mu \mathrm{L}$ total volume containing $2 \mu \mathrm{L}$ of the first PCR product and the same concentration of the first PCR reagents. To check if the PCRs had been successful, $2.5 \mu \mathrm{L}$ of the final PCR product was run on a $2 \%$ agarose gel. Negative (ultrapure water) and positive (microscopy-positive samples) controls were used to verify the results of every PCR run. All PCR products were purified and sequenced by Microsynth AG (Balgach, Switzerland).

The sequences of 479 base pairs of the cytb gene were edited and aligned in BioEdit [89], then they were compared with lineages available in the MalAvi Public Database (MalAvi http:/ / mbio-serv2.mbioekol.lu.se/Malavi/, accessed on 1 May 2021) and National Center for Biotechnology Information (NCBI) (https: / /blast.ncbi.nlm.nih.gov/Blast.cgi, accessed on 1 May 2021). The sequences possessing at least one different nucleotide were considered as new lineages and were named according to the MalAvi nomenclature. Sequences with double peaks in the chromatograms were identified as unresolved co-infections. New sequences and unresolved co-infections were sequenced from the 3'end using HaemR2 (Haemoproteus-Plasmodium spp.-positive samples) or HaemR2L (Leucocytozoon spp.-positive samples) for the sequence validation, and unresolved co-infections were excluded from the analysis. All obtained DNA sequences were deposited in GenBank (accession numbers MT925798-MT925931, see Table 1).

\subsection{Statistical Analysis}

Statistical analysis was performed using Statistical Package for the Social Sciences (SPSS) for windows, version 14.0 (SPSS Inc., Chicago, IL, USA). To assess prevalence differences among bird species and birds of different families as well as correlation of simultaneous presence of multiple parasite genera in a bird host, one-way ANOVA and Pearson correlation tests were used, as reported in the text. Only data on birds belonging to five most extensively sampled families (Acrocephalidae, Muscicapidae, Passeridae, Pycnonotidae, Sylviidae), were incorporated in the statistical analysis, aiming to a comparative prevalence analysis. In each bird family, over 14 individuals were sampled (Table 1).

\section{Conclusions}

This study revealed a high prevalence and diversity of haemosporidian parasites in passerines in Iran and provides extended information about the distribution of these infections in southern Asia. In all, 93 parasite lineages were reported in birds in Iran. Notably, 36 lineages, including 15 new lineages, were found in the resident (non-migrating) bird species, indicating active local transmission of haemosporidiosis and calling for further research on these blood parasites. It is important to note that the invasive lineages SGS1 and GRW4 of P. relictum, which cause virulent avian malaria, are present and transmitted in sympatry in Iran. The common presence of co-infections, which are often more virulent than single infections, shows that haemosporidians might be important for wild bird health in this region. Further studies are needed to understand the epidemiological patterns of avian haemosporidiosis and the role of these diseases in natural ecosystems. This study determined the most convenient avian model hosts and common haemosporidian parasites lineages for such research in southern Iran.

Author Contributions: Conceptualization: M.A., O.M., V.G.; Methodology: V.G., M.A., O.M., G.V.; Formal analysis and investigation: V.G., M.A.; Writing-original draft preparation: V.G., M.A.; Writingreview and editing: V.G., M.A., O.M., G.V.; Supervisions: M.A., O.M. All authors have read and agreed to the published version of the manuscript.

Funding: This study was financially supported by the Faculty of Science, Ferdowsi University of Mashhad (FUM; grant No.3.45945 to VG) and Iran National Science Foundation (INSF; grant No.96016392 to VG). 
Institutional Review Board Statement: The authors declare that all applicable guidelines for capturing and collecting biological samples from animals were followed. These guidelines come from the ethical principles and the national norms and standards for conducting Medical Research of Ferdowsi University of Mashhad, Iran (Ethics Certificate Number: IR.UM.REC.1400.028). Furthermore, all field works were carried out with permission and approval by the Department of the Environment for sample collection (permits numbers: 96/5612, 122-902, 97/773,97/10/1/744) of each location in this study. All birds were released after sampling, and all efforts were made to minimize their suffering.

Informed Consent Statement: Not applicable.

Data Availability Statement: The amplified sequences of the parasite lineages (mitochondrial $c y t b$ gene) were deposited in GenBank (Accession numbers MT925798-MT925931).

Acknowledgments: We are grateful to the Department of Environment of Iran for their encouragement and support of all necessary permits and field sampling (permits numbers: 96/5612, 122-902, 97/773, 97/10/1/744). The authors would like to thank all those colleagues who assisted in the sampling, especially Seyed Hashem Ghaemitalab, Mahmoud Jokar, Raziyeh Abdillzadeh, Mahdi Elahi, Behzad Bijestani, Shahrbanoo Ashtari and Mahsa Moosavi. We are also immensely grateful to the Environment protection organizations of Khuzestan (Ahwaz and Karkheh protected area), Bushehr (Bushehr and Heleh protected area) and Sistan and Baluchistan (Zahedan, Rask, Mehrestan and Saravan), especially to dear Shirmohammadi and Delshab who provided us with the facilities needed for sampling and to Staffan Bensch, Lund University, for his invaluable comments on an earlier version of the manuscript and valuable contribution to methodologic and technical aspects of this manuscript.

Conflicts of Interest: The authors declare that they have no conflict of interest.

\section{References}

1. Valkiūnas, G. Avian Malaria Parasites and other Haemosporidia; Apple Academic Press: Boca Raton, FL, USA, 2004.

2. Atkinson, C.T.; Thomas, N.J.; Hunter, D.B. Parasitic Diseases of Wild Birds; John Wiley \& Sons: Ames, IA, USA, 2008 ; pp. 3-107.

3. Telford, S.R., Jr. Haemoparasites of the Reptilia, Color Atlas and Text; CRC Press: Boca Raton, FL, USA, 2009.

4. Clark, N.J.; Clegg, S.M.; Lima, M.R. A review of global diversity in avian haemosporidians (Plasmodium and Haemoproteus: Haemosporida): New insights from molecular data. Int. J. Parasitol. 2014, 44, 329-338. [CrossRef]

5. Marzal, A.; Bensch, S.; Reviriego, M.I.; Balbontin, J.; De Lope, F. Effects of malaria double infection in birds: One plus one is not two. J. Evol. Biol. 2008, 21, 979-987. [CrossRef]

6. Dimitrov, D.; Zehtindjiev, P.; Bensch, S. Genetic diversity of avian blood parasites in SE Europe: Cytochrome b lineages of the genera Plasmodium and Haemoproteus (Haemosporida) from Bulgaria. Acta Parasitol. 2010, 55, 201-209. [CrossRef]

7. Lapointe, D.A.; Atkinson, C.T.; Samuel, M.D. Ecology and conservation biology of avian malaria. Ann. N.Y. Acad. Sci. 2012, 1249, 211-226. [CrossRef]

8. Graham, A.L.; Lamb, T.J.; Read, A.F.; Allen, J.E. Malaria-Filaria Coinfection in Mice Makes Malarial Disease More Severe unless Filarial Infection Achieves Patency. J. Infect. Dis. 2005, 191, 410-421. [CrossRef] [PubMed]

9. Davidar, P.; Morton, E.S. Are Multiple Infections More Severe for Purple Martins (Progne Subis) Than Single Infections? Auk 2006, 123, 141-147. [CrossRef]

10. Atkinson, C.T.; Van Riper, C., III. Pathogenicity and epizootiology of avian haematozoa: Plasmodium, Leucocytozoon, and Haemoproteus. In Bird-Parasite Interactions: Ecology, Evolution, and Behaviour, 2rd ed.; Oxford University Press: Cary, NC, USA; New York, NY, USA, 1991; pp. 19-48.

11. Bensch, S.; Stjernman, M.; Hasselquist, D.; Örjan, Ö.; Hansson, B.; Westerdahl, H.; Pinheiro, R.T. Host specificity in avian blood parasites: A study of Plasmodium and Haemoproteus mitochondrial DNA amplified from birds. Proc. R. Soc. B Boil. Sci. 2000, 267, 1583-1589. [CrossRef] [PubMed]

12. Bensch, S.; Hellgren, O.; Pérez-Tris, J. MalAvi: A public database of malaria parasites and related haemosporidians in avian hosts based on mitochondrial cytochrome b lineages. Mol. Ecol. Resour. 2009, 9, 1353-1358. [CrossRef]

13. Okwa, O. Malaria Parasites; InTech: Rijeka, Croatia, 2012.

14. MalAvi. A Database for Avian Haemosporidian Parasites. Table: Host and Sites. Available online: http://mbio-serv2.mbioekol. lu.se/Malavi/ (accessed on 23 April 2021).

15. Jarvi, S.I.; Schultz, J.J.; Atkinson, C.T. PCR diagnostics underestimate the prevalence of avian malaria (Plasmodium relictum) in experimentally-infected passerines. J. Parasitol 2002, 88, 153-158. [CrossRef]

16. Pellegrino, I.; Ilahiane, L.; Boano, G.; Cucco, M.; Pavia, M.; Prestridge, H.; Voelker, G. Avian Haemosporidian Diversity on Sardinia: A First General Assessment for the Insular Mediterranean. Diversity 2021, 13, 75. [CrossRef]

17. Van Hemert, C.; Meixell, B.W.; Smith, M.M.; Handel, C.M. Prevalence and diversity of avian blood parasites in a resident northern passerine. Parasit Vectors 2019, 12, 292. [CrossRef] 
18. Khaleghizadeh, A.; Roselaar, K.; Scott, D.A.; Tohidifar, M.; Mlíkovský, J.; Blair, M.; Kvartalnov, P. Birds of Iran: Annotated Checklist of the Species and Subspecies; Iranian Research Institute of Plant Protection: Tehran, Iran, 2017.

19. Madjnoonian, H.; Kiabi, B.H.; Danesh, M. Readings in Zoogeography of Iran: Part I; Department of Environment: Tehran, Iran, 2005.

20. Evans, M.I. Important Bird Areas in the Middle East; Birdlife International: Cambridge, UK, 1994.

21. Nazifi, S.; Razavi, S.M.; Yavari, F.; Rajaifar, M.; Bazyar, E.; Esmailnejad, Z. Evaluation of hematological values in indigenous chickens infected with Plasmodium gallinaceum and Aegyptianella pullorum. Comp. Haematol. Int. 2008, 17, 145-148. [CrossRef]

22. Radfar, M.H.; Fathi, S.; Asl, E.N.; Dehaghi, M.M.; Seghinsara, H.R. A survey of parasites of domestic pigeons (Columba livia domestica) in South Khorasan, Iran. Vet. Res. 2011, 4, 18-23. [CrossRef]

23. Gorji, S.F.; Shemshadi, B.; Habibi, H.; Jalali, S.; Davary, M.; Sepehri, M. Survey on parasites in sparrows of Amol (Mazandaran Province, Iran). J. Life Sci. 2012, 6, 783-785.

24. Dehghani Samani, A.; Pirali Kheirabadi, K. Prevalence and Rate of Parasitemia of Haemoproteus columbae in Columba Iivia domestica Southwest of Iran. Iran J. Parasitol. 2013, 8, 641-644. [PubMed]

25. Dezfoulian, O.; Zibaei, M.; Nayebzadeh, H.; Haghgoo, M.; Emami-Razavi, A.; Kiani, K. Leucocytozoonosis in Domestic Birds in Southwestern Iran: An Ultrastructural Study. Iran J. Parasitol. 2013, 8, 171-176. [PubMed]

26. Doosti, A.; Mohammadalipour, Z.; Zohoor, A. Detection of Haemoproteus Columbae in Iranian Pigeons Using PCR. Int. Conf. Biol. Civ. Environ. Eng. (BCEE-2014) 2014, 36, 8. [CrossRef]

27. Shemshadi, B.; Ranjbar-Bahadori, S.; Faghihzadeh-Gorgi, S. Occurrence of parasitic protozoa in wild waterfowl in southern coastal Caspian Sea lagoons. Iran J. Vet. Med. 2015, 8, 261-267. [CrossRef]

28. Tavassoli, M.; Esmaeilnejad, B.; Malekifard, F.; Mardani, K. PCR-RFLP detection of Haemoproteus spp. (Haemosporida: Haemoproteidae) in pigeon blood samples from Iran. Bulg. J. Veter-Med. 2018, 21, 429-435. [CrossRef]

29. Mohaghegh, M.A.; Namdar, F.; Azami, M.; Ghomashlooyan, M.; Kalani, H.; Hejazi, S.H. The first report of blood parasites in the birds in Fasa district, Southern Iran. Comp. Haematol. Int. 2018, 27, 289-293. [CrossRef]

30. Hashemi, S.H.; Sargazi, D.; Anvari, D. The study of Lico contamination by Haemoproteus spp in Sistan region. Biol. Forum 2015, 7, 757-758.

31. Nourani, L.; Aliabadian, M.; Mirshamsi, O.; Djadid, N.D. Correction: Molecular detection and genetic diversity of avian haemosporidian parasites in Iran. PLoS ONE 2019, 14, e0212453. [CrossRef] [PubMed]

32. Cracraft, J. Deep-history biogeography: Retrieving the historical pattern of evolving continental biotas. Syst. Biol. 1988, 37, 221-236. [CrossRef]

33. Dickinson, E.C.; Christidis, L. The Howard and Moore Complete Checklist of the Birds of the World: Passerines, 4th ed.; Aves Press: Eastbourne, UK, 2014.

34. Cornuault, J.; Khimoun, A.; Harrigan, R.J.; Bourgeois, Y.X.C.; Mila, B.; Thébaud, C.; Heeb, P. The role of ecology in the geographical separation of blood parasites infecting an insular bird. J. Biogeogr. 2013, 40, 1313-1323. [CrossRef]

35. Hernández-Lara, C.; Gonzalez-Garcia, F.; Santiago-Alarcon, D. Spatial and seasonal variation of avian malaria infections in five different land use types within a Neotropical montane forest matrix. Landsc. Urban Plan. 2017, 157, 151-160. [CrossRef]

36. Martinsen, E.S.; Paperna, I.; Schall, J.J. Morphological versus molecular identification of avian Haemosporidia: An exploration of three species concepts. Parasitology 2006, 133, 279-288. [CrossRef]

37. Marzal, A.; Ricklefs, R.E.; Valkiūnas, G.; Albayrak, T.; Arriero, E.; Bonneaud, C.; Czirják, G.Á.; Ewen, J.; Hellgren, O.; Hořáková, D.; et al. Diversity, Loss, and Gain of Malaria Parasites in a Globally Invasive Bird. PLoS ONE 2011, 6, e21905. [CrossRef]

38. Martinsen, E.S.; Perkins, S.L.; Schall, J.J. A three-genome phylogeny of malaria parasites (Plasmodium and closely related genera): Evolution of life-history traits and host switches. Mol. Phylogenetics Evol. 2008, 47, 261-273. [CrossRef]

39. Loiseau, C.; Zoorob, R.; Robert, A.; Chastel, O.; Julliard, R.; Sorci, G. Plasmodium relictum infection and MHC diversity in the house sparrow (Passer domesticus). Proc. R. Soc. B Boil. Sci. 2010, 278, 1264-1272. [CrossRef]

40. López, G.; Muñoz, J.; Soriguer, R.; Figuerola, J. Increased Endoparasite Infection in Late-Arriving Individuals of a Trans-Saharan Passerine Migrant Bird. PLoS ONE 2013, 8, e61236. [CrossRef]

41. Mata, V.A.; Da Silva, L.P.; Lopes, R.J.; Drovetski, S.V. The Strait of Gibraltar poses an effective barrier to host-specialised but not to host-generalised lineages of avian Haemosporidia. Int. J. Parasitol. 2015, 45, 711-719. [CrossRef] [PubMed]

42. Calero-Riestra, M.; García, J.T. Sex-dependent differences in avian malaria prevalence and consequences of infections on nestling growth and adult condition in the Tawny pipit, Anthus campestris. Malar. J. 2016, 15, 1-11. [CrossRef] [PubMed]

43. Gutiérrez-López, R.; La Puente, J.M.-D.; Gangoso, L.; Yan, J.; Soriguer, R.C.; Figuerola, J. Do mosquitoes transmit the avian malaria-like parasite Haemoproteus? An experimental test of vector competence using mosquito saliva. Parasites Vectors 2016, 9 , 1-7. [CrossRef]

44. Ayadi, T.; Selmi, S.; Hammouda, A.; Reis, S.; Boulinier, T.; Loiseau, C. Diversity, prevalence and host specificity of avian parasites in southern Tunisian oases. Parasitology 2017, 145, 971-978. [CrossRef]

45. Emmenegger, T.; Bauer, S.; Dimitrov, D.; Marin, J.O.; Zehtindjiev, P.; Hahn, S. Host migration strategy and blood parasite infections of three sparrow species sympatrically breeding in Southeast Europe. Parasitol. Res. 2018, 117, 3733-3741. [CrossRef]

46. Garcia-Longoria, L.; Marzal, A.; De Lope, F.; Garamszegi, L. Host-parasite interaction explains variation in the prevalence of avian haemosporidians at the community level. PLOS ONE 2019, 14, e0205624. [CrossRef]

47. Waldenström, J.; Bensch, S.; Kiboi, S.; Hasselquist, D.; Ottosson, U. Cross-species infection of blood parasites between resident and migratory songbirds in Africa. Mol. Ecol. 2002, 11, 1545-1554. [CrossRef] 
48. Drovetski, S.V.; Aghayan, S.A.; Mata, V.; Lopes, R.J.; Mode, N.A.; Harvey, J.A.; Voelker, G. Does the niche breadth or trade-off hypothesis explain the abundance-occupancy relationship in avian Haemosporidia? Mol. Ecol. 2014, 23, 3322-3329. [CrossRef] [PubMed]

49. Santiago-Alarcon, D.; MacGregor-Fors, I.; Kühnert, K.; Segelbacher, G.; Schaefer, H.M. Avian haemosporidian parasites in an urban forest and their relationship to bird size and abundance. Urban Ecosyst. 2016, 19, 331-346. [CrossRef]

50. Peev, S.; Zehtindjiev, P.; Ilieva, M.; Träff, J.; Briedis, M.; Adamík, P. Haemosporidian blood parasite diversity and prevalence in the semi-collared flycatcher (Ficedula semitorquata) from the eastern Balkans. Parasitol. Int. 2016, 65, 613-617. [CrossRef]

51. Stanković, D.; Jönsson, J.; Raković, M. Diversity of avian blood parasites in wild passerines in Serbia with special reference to two new lineages. J. Ornithol. 2019, 160, 545-555. [CrossRef]

52. Hellgren, O.; Waldenström, J.; Pérez-Tris, J.; Szöll, E.; Si, Ö.; Hasselquist, D.; Križanauskienè, A.; Ottosson, U.; Bensch, S. Detecting shifts of transmission areas in avian blood parasites-A phylogenetic approach. Mol. Ecol. 2007, 16, 1281-1290. [CrossRef]

53. Zehtindjiev, P.; Ilieva, M.; Križanauskienè, A.; Oparina, O.; Oparin, M.; Bensch, S. Occurrence of haemosporidian parasites in the paddyfield warbler, Acrocephalus agricola (Passeriformes, Sylviidae). Acta Parasitol. 2009, 54, 295-300. [CrossRef]

54. Spurgin, L.G.; Illera, J.C.; Padilla, D.P.; Richardson, D.S. Biogeographical patterns and co-occurrence of pathogenic infection across island populations of Berthelot's pipit (Anthus berthelotii). Oecologia 2012, 168, 691-701. [CrossRef] [PubMed]

55. Rojo, M.A.; Campos, F.; Santamaría, T.; Hernández, M.A. Haemosporidians in Iberian Bluethroats Luscinia svecica. Ardeola 2014, 61, 135-143. [CrossRef]

56. Ivanova, K.; Zehtindjiev, P.; Mariaux, J.; Dimitrov, D.; Georgiev, B.B. Avian haemosporidians from rain forests in Madagascar: Molecular and morphological data of the genera Plasmodium, Haemoproteus and Leucocytozoon. Infect. Genet. Evol. 2018, 58, 115-124. [CrossRef]

57. Ortego, J.; Calabuig, G.; Cordero, P.J.; Aparicio, J.M. Genetic characterization of avian malaria (Protozoa) in the endangered lesser kestrel, Falco naumanni. Parasitol. Res. 2007, 101, 1153-1156. [CrossRef] [PubMed]

58. Illera, J.C.; Emerson, B.C.; Richardson, D.S. Genetic characterization, distribution and prevalence of avian pox and avian malaria in the Berthelot's pipit (Anthus berthelotii) in Macaronesia. Parasitol. Res. 2008, 103, 1435-1443. [CrossRef]

59. Synek, P.; Albrecht, T.; Vinkler, M.; Schnitzer, J.; Votýpka, J.; Munclinger, P. Haemosporidian parasites of a European passerine wintering in South Asia: Diversity, mixed infections and effect on host condition. Parasitol. Res. 2013, 112, 1667-1677. [CrossRef] [PubMed]

60. Van Riper, C.; Van Riper, S.G.; Goff, M.L.; Laird, M. The Epizootiology and Ecological Significance of Malaria in Hawaiian Land Birds. Ecol. Monogr. 1986, 56, 327-344. [CrossRef]

61. Valkiūnas, G.; Ilgūnas, M.; Bukauskaitè, D.; Fragner, K.; Weissenböck, H.; Atkinson, C.T.; Iezhova, T.A. Characterization of Plasmodium relictum, a cosmopolitan agent of avian malaria. Malar. J. 2018, 17, 184. [CrossRef] [PubMed]

62. Van Rooyen, J.; Lalubin, F.; Glaizot, O.; Christe, P. Avian haemosporidian persistence and co-infection in great tits at the individual level. Malar. J. 2013, 12, 40. [CrossRef] [PubMed]

63. Valkiūnas, G.; Iezhova, T.A.; Shapoval, A.P. High prevalence of blood parasites in hawfinch Coccothraustes coccothraustes. J. Nat. Hist. 2003, 37, 2647-2652. [CrossRef]

64. Scaglione, F.E.; Pregel, P.; Cannizzo, F.T.; Pérez-Rodríguez, A.D.; Ferroglio, E.; Bollo, E. Prevalence of new and known species of haemoparasites in feral pigeons in northwest Italy. Malar. J. 2015, 14, 99. [CrossRef]

65. Meixell, B.W.; Arnold, T.W.; Lindberg, M.S.; Smith, M.M.; Runstadler, J.A.; Ramey, A.M. Detection, prevalence, and transmission of avian haematozoa in waterfowl at the Arctic/sub-Arctic interface: co-infections, viral interactions, and sources of variation. Parasites Vectors 2016, 9, 390. [CrossRef] [PubMed]

66. Bernotienè, R.; Palinauskas, V.; Iezhova, T.; Murauskaite, D.; Valkiūnas, G. Avian haemosporidian parasites (Haemosporida): A comparative analysis of different polymerase chain reaction assays in detection of mixed infections. Exp. Parasitol. 2016, 163, 31-37. [CrossRef]

67. Pacheco, M.A.; Cepeda, A.S.; Bernotienè, R.; Lotta, I.A.; Matta, N.E.; Valkiūnas, G.; Escalante, A.A. Primers targeting mitochondrial genes of avian haemosporidians: PCR detection and differential DNA amplification of parasites belonging to different genera. Int. J. Parasitol. 2018, 48, 657-670. [CrossRef]

68. Ciloglu, A.; Ellis, V.A.; Bernotiene, R.; Valkiūnas, G.; Bensch, S. A new one-step multiplex PCR assay for simultaneous detection and identification of avian haemosporidian parasites. Parasitol. Res. 2019, 118, 191-201. [CrossRef]

69. Pérez-Tris, J.; Bensch, S. Diagnosing genetically diverse avian malarial infections using mixed-sequence analysis and TA-cloning. Parasitology 2005, 131, 15-23. [CrossRef]

70. Zehtindjiev, P.; Križanauskienè, A.; Bensch, S.; Palinauskas, V.; Asghar, M.; Dimitrov, D.; Scebba, S.; Valkiūnas, G. A New Morphologically Distinct Avian Malaria Parasite That Fails Detection by Established Polymerase Chain Reaction-Based Protocols for Amplification of the Cytochrome B Gene. J. Parasitol. 2012, 98, 657-665. [CrossRef]

71. Richard, F.A.; Sehgal, R.N.; Jones, H.I.; Smith, T.B. A comparative analysis of PCR-based detection methods for avian malaria. J. Parasitol. 2002, 88, 819-822. [CrossRef]

72. Beadell, J.S.; Fleischer, R.C. A Restriction Enzyme-Based Assay to Distinguish Between Avian Haemosporidians. J. Parasitol. 2005, 91, 683-685. [CrossRef] 
73. Martinez, J.; de la Puente, J.M.; Herrero, J.; Del Cerro, S.; Lobato, E.; Aguilar, J.R.-D.; Vásquez, R.A.; Merino, S. A restriction site to differentiate Plasmodium and Haemoproteus infections in birds: On the inefficiency of general primers for detection of mixed infections. Parasitology 2009, 136, 713-722. [CrossRef]

74. Dimitrov, D.; Zehtindjiev, P.; Bensch, S.; Ilieva, M.; Iezhova, T.; Valkiūnas, G. Two new species of Haemoproteus Kruse, 1890 (Haemosporida, Haemoproteidae) from European birds, with emphasis on DNA barcoding for detection of haemosporidians in wildlife. Syst. Parasitol. 2014, 87, 135-151. [CrossRef]

75. Dimitrov, D.; Palinauskas, V.; Iezhova, T.A.; Bernotienè, R.; Ilgūnas, M.; Bukauskaitè, D.; Zehtindjiev, P.; Ilieva, M.; Shapoval, A.P.; Bolshakov, C.V.; et al. Plasmodium spp.: An experimental study on vertebrate host susceptibility to avian malaria. Exp. Parasitol. 2015, 148, 1-16. [CrossRef]

76. Loiseau, C.; Zoorob, R.; Garnier, S.; Birard, J.; Federici, P.; Julliard, R.; Sorci, G. Antagonistic effects of a MHC class I allele on malaria-infected house sparrows. Ecol. Lett. 2008, 11, 258-265. [CrossRef] [PubMed]

77. Hasselquist, D.; Östman, Ö.; Waldenström, J.; Bensch, S. Temporal Patterns of Occurrence and Transmission of the Blood Parasite Haemoproteus Payevskyi in the Great Reed Warbler Acrocephalus Arundinaceus. J. Ornithol. 2007, 148, 401-409. [CrossRef]

78. Palinauskas, V.; Valkiūnas, G.; Bolshakov, C.V.; Bensch, S. Plasmodium relictum (lineage SGS1) and Plasmodium ashfordi (lineage GRW2): The effects of the co-infection on experimentally infected passerine birds. Exp. Parasitol. 2011, 127, 527-533. [CrossRef]

79. Pigeault, R.; Cozzarolo, C.-S.; Choquet, R.; Strehler, M.; Jenkins, T.; Delhaye, J.; Bovet, L.; Wassef, J.; Glaizot, O.; Christe, P. Haemosporidian infection and co-infection affect host survival and reproduction in wild populations of great tits. Int. J. Parasitol. 2018, 48, 1079-1087. [CrossRef] [PubMed]

80. Lapointe, D.A.; Goff, M.L.; Atkinson, C.T. Thermal Constraints to the Sporogonic Development and Altitudinal Distribution of Avian Malaria Plasmodium relictum in Hawai'i. J. Parasitol. 2010, 96, 318-324. [CrossRef] [PubMed]

81. Santiago-Alarcon, D.; Palinauskas, V.; Schaefer, H.M. Diptera vectors of avian Haemosporidian parasites: untangling parasite life cycles and their taxonomy. Biol. Rev. 2012, 87, 928-964. [CrossRef]

82. Zehtindjiev, P.; Ilieva, M.; Westerdahl, H.; Hansson, B.; Valkiūnas, G.; Bensch, S. Dynamics of parasitemia of malaria parasites in a naturally and experimentally infected migratory songbird, the great reed warbler Acrocephalus arundinaceus. Exp. Parasitol. 2008, 119, 99-110. [CrossRef] [PubMed]

83. Schoener, E.R.; Tompkins, D.M.; Parker, K.A.; Howe, L.; Castro, I. Presence and diversity of mixed avian Plasmodium spp. infections in introduced birds whose distribution overlapped with threatened New Zealand endemic birds. N. Z. Vet. J. 2019, 68, 101-106. [CrossRef] [PubMed]

84. Evans, M.; Otter, A. Fatal combined infection with Haemoproteus noctuae and Leucocytozoon ziemanni in juvenile snowy owls (Nyctea scandiaca). Veter-Rec. 1998, 143, 72-76. [CrossRef] [PubMed]

85. De Roode, J.C.; Helinski, M.E.H.; Anwar, M.A.; Read, A.F. Dynamics of Multiple Infection and Within-Host Competition in Genetically Diverse Malaria Infections. Am. Nat. 2005, 166, 531-542. [CrossRef] [PubMed]

86. Svensson, L.; Mullarney, K.; Zetterström, D. Collins Bird Guide, 2nd ed.; British Birds; HarperCollins: London, UK, 2010.

87. Bruford, M.W.; Hanotte, O.; Brookfield, J.F.Y.; Burke, T. Single-locus and multilocus DNA fingerprinting. In Molecular Genetic Analysis of Populations: A Practical Approach; Hoelzel, A.R., Ed.; IRL Press: Oxford, UK, 1992; pp. 225-269.

88. Hellgren, O.; Waldenström, J.; Bensch, S. A new PCR assay for simultaneous studies of leucocytozoon, plasmodium, and haemoproteus from avian blood. J. Parasitol. 2004, 90, 797-802. [CrossRef] [PubMed]

89. Hall, T.A. BioEdit: A user-friendly biological sequence alignment editor and analysis program for Windows 95/98/NT. Nucl. Acids Symp. Ser. 1999, 41, 95-98. 